Danjie Su* and Hongyin Tao

\title{
Teaching the Mandarin utterance-final particle le through authentic materials
}

https://doi.org/10.1515/caslar-2018-0002

\begin{abstract}
The Mandarin utterance-final particle le is among the most difficult and elusive grammatical features that learners of Chinese often encounter, owing to its rich interactional pragmatic functions and the lack of a counterpart in many first languages. In this article, we use media clips to illustrate a beginning-level language teaching unit for this feature. We show that authentic materials can be used to address pedagogical issues with some of the most difficult grammatical phenomena in Chinese and that this can be accomplished via material design, classroom activities, and assessment methods - all at the beginning level. (All relevant video clips used in this article can be found from this website: http://clicresearch.rice.edu/caslar-authentic-spoken-language/\#le)
\end{abstract}

Keywords: le, utterance-final particle, authentic materials, Chinese as a second language, elementary Chinese

摘要: 汉语句末助词 “了” 由于语用互动功能丰富、再加上学习者的第一语言中往 往缺乏对应结构, 一直以来是汉语第二语言学习的语法难点之一。本文以影视片 段为素材, 展示初级阶段的语言教学如何利用真实材料教语法, 包括语法构式在 具体语境下的使用和非使用条件。我们的教学设计显示, 真实材料可以用于语法 难点的教学, 而且在初级阶段就可以运用-一包括教学材料、课堂活动和测试手 段。

\section{Introduction}

This article illustrates a beginning-level language lesson design that uses authentic materials to teach an elusive spoken element in Mandarin - the utterance-final particle le. Authentic materials are language samples that are "not ... specifically produced for the purpose of language teaching" (Nunan 1989: 54). Authentic materials have increasingly been recognized as being beneficial for language learning (e.g., Gilmore 2007, 2011; Mishan 2005; Pinner

\footnotetext{
*Corresponding author: Danjie Su, Department of World Languages, Literatures \& Cultures, University of Arkansas, Fayetteville, Arkansas 72701, USA, E-mail: danjiesu@uark.edu Hongyin Tao, Department of Asian Languages and Cultures, University of California, Los Angeles, California 90095-1540, USA, E-mail: tao@humnet.ucla.edu
} 
2013; Tao 2005a, 2005b; Webb 2010; Zyzik and Polio 2017). While there have been ample spoken language teaching materials (especially at the advanced level) based on authentic materials (e.g., for English textbooks, see Carter and McCarthy 1997; for Chinese textbooks, see Tao 2011), much of language teaching is based on contrived data, especially at the beginning level. We agree with a number of previous studies that authentic materials can be used for beginning level and for grammar teaching (McGinnis 1990; Su and Tao 2014; Zyzik and Polio 2017). What is needed is more teaching samples showing language instructors exactly how it can be done. By selecting the utterance-final particle le, we hope to accomplish just that. The authentic materials used in this unit are media clips from such sources as films and TV shows, which are rich in interactive spoken language features.

\subsection{Utterance-final particle le}

Utterance-final particles are a robust feature characterizing many Asian languages. They are a type of lexicogrammatical element that typically has no lexical meanings yet are critical in expressing a wide range of interactive pragmatic functions. This is especially the case with the particle le. The following example (Li and Thompson 1981: 243) shows how the utterance-final particle le is used at the end of a clause/utterance.

(1) 她出去买东西了。

Ta chuqu mai dongxi le.

'She's gone shopping.'

Many studies have been dedicated to capturing the functions of this particle (see, e.g., Chao 1968; Chan 1980; Chen 2009; van den Berg and Wu 2006; Soh 2009; Liu, M. 2015). For example, Chao (1968: 798-800) observes seven uses of the particle le: (1) inchoative; (2) command in response to a new situation; (3) progress in a story; (4) isolated event in the past; (5) completed action as of the present; (6) consequent clause to indicate situation; (7) 'obviousness.' Van den Berg and $\mathrm{Wu}$ (2006) argue that the particle le is a "common-ground coordination device" that indexes a co-ordination point; namely, it focuses the attention of both the speaker and the addressee on the structure of the shared common ground as of that moment and requests the addressee to bring the information into the shared personal common ground.

Further complicating the situation is the fact that besides the utterance-final particle le (called le2 in the literature), there is another grammatical element that 
has the same form - the verb suffix le (called le1 in the literature). While they can be distinguished when present at their respective positions, sometimes they conflate when the utterance ends with the main verb taking a le form. Still, in both the fields of Chinese linguistics and Chinese applied linguistics, there is a general consensus that the distinction between the two types of le should be maintained where no conflation is at issue. Considering that the utterance-final particle le2 is more difficult for second language learners to acquire than the verb suffix le1 (e.g., Wen 1995; Wang Q. and Peng 2013; Zhou and Ouyang 2014), in this article, we focus on the teaching of the utterance-final particle le2 (henceforth, we will simply use le to designate le2 unless otherwise noted). With the selected video clips, we emphasize in this teaching unit the contexts in which this utterance-final particle is used and how speakers use it to achieve interactional goals - arguably some of the most distinct advantages of using authentic materials in language teaching.

\subsection{Existing textbook explanations based on non-authentic materials}

Due to the wide range of uses and the complexity that comes from the interaction of the two le forms, le and the associated properties are a target of much Chinese pedagogical efforts. Course books typically introduce some form of le at the elementary level. In a widely adopted first-year Chinese textbook, Integrated Chinese (Liu et al. 2009), for example, le is first introduced in Level 1, Part 1, Lesson 5 (pp. 137-139). Below are the grammar notes from the textbook.

\footnotetext{
The dynamic particle le signifies: (1) the occurrence or completion of an action or event, or (2) the emergence of a situation. The action, event, or situation usually pertains to the past, but sometimes it can refer to the future. Therefore $l e$ is not a past tense marker, and the use of $l e$ should not be taken as an equivalent to the past tense in English. In this lesson, le indicates the occurrence or completion of an action or event. It is usually used after a verb. But sometimes it appears after a verb and the object of the verb in interrogative and declarative sentences.
}

The textbook then provides some isolated example sentences illustrating the points, some of which are provided below:

（2）星期一小高请我喝了一瓶可乐。

Xingqiyi Xiao Gao qing wo he le yi ping kele.

'On Monday Little Gao bought me a bottle of cola.'

(occurrence or completion of an event, in the past) 
昨天晚上我去打球了。

Zuotian wanshang wo qu da qiu le.

'Yesterday evening I went to play ball.'

(occurrence or completion of an event, in the past)

Despite the alleged advantages that conventional language textbooks are said to have, a few critical limitations can be observed in the textbook sample just cited. First, the explanations do not distinguish verb suffix le1 from utterance-final particle le2, leaving much confusion to the learner about these two tokens, in addition to the already confusing functions that each of them carries. Second, the explanations (e.g., "It is usually used... but sometimes it appears") do not touch on the subtle yet important interactional pragmatic functions of $l e$. When such attempts are made, the information is sometimes misleading. For example, in (3), the explanation "occurrence or completion of an event, in the past" does not accurately describe what the sentence communicates as it is not necessarily intended to convey a completion meaning, and this explanation fails to recognize that the le token used here is the utterance-final particle $l e 2$ and not the verb suffix le1. Third, the isolated example sentences fail to provide any sort of context, which is often critical to understanding the use of $l e$.

As a number of pioneering studies have shown, the lack of authentic materials in grammar teaching is a much more widely accepted practice than the case of le alone. Tao (2005a) examines three major elementary spoken Chinese textbooks compiled in China, the U.S., and Great Britain in light of the discourse linguistic patterns revealed in natural data and finds that in terms of spoken language features, conversational strategies, and contextual factors, "there is a severe lack of authenticity in the materials taught and tested in the field of teaching Chinese as a second language.... This situation is taken to be representative of the state of the art of our field." A problem with using nonauthentic materials of this kind is that learners are left without knowing how to use the grammatical construction in question. We will explore this issue in detail in the next section.

\subsection{Acquisition of the utterance-final particle le}

Due to its elusive pragmatic functions, le has proven to be difficult in a number of ways for second language learners to acquire (e.g., Ding 2012; Liu H. and Ding 2015; Liu Y. 2015; Wang Q. and Peng 2013; Wang Y. 2015; Wen 1995; Zhou and Ouyang 2014). A major issue learners have is omission (Ellis 1994: 56) of the particle when the context calls for it. This is especially the case for learners 
whose first language is English (Wen 1995; Yu 1999; Wang Q. and Peng 2013), Japanese (Zhou and Ouyang 2014), or Korean (Wang Y. 2015).

Using interviews and picture-based tasks, Wen (1995) conducts a study on the acquisition of le by both beginning-level students who have been learning Chinese for 14 months and by more advanced students who had been learning Chinese for 26 months at an American college. She finds that only $41.5 \%$ of the subjects at the beginning level correctly used the utterance-final particle le. This number increases to $77.3 \%$ at the more advanced level.

A recent study in Zhou and Ouyang (2014) uses a subset (175,000 Chinese characters) of the Sun Yat-sen University L2 Chinese Corpus and finds that omissions account for almost two thirds (64\%) of the errors learners made with the utterance-final particle le. The findings are even more striking when considering the extensive language background of the learners- Japanese students who studied Chinese as a second language at a university in China and who received five days of Chinese language instructions a week (at least 20 class hours/week) for at least one year and lived in China. Zhou and Ouyang's (2014) investigation of the HSK L2 Written Chinese Monitoring Corpus by Beijing Language and Culture University found similar error patterns. Thus, Zhou and Ouyang's (2014) results very much corroborate the findings of Wen (1995).

For other less frequent error types, the interested reader is referred to a large number of studies on this topic (e.g., Ding 2012; Liu H. and Ding 2015; Liu Y. 2015; Wang Q. and Peng 2013; Wang Y. 2015; Wen 1995; Zhou and Ouyang 2014). In general, the findings regarding learners' acquisition show that, although features of language and ways to acquire them are not the same, it is critical to expose learners to the concrete contexts and ways L1 speakers use the utterance-final particle $l e$, and we believe that carefully selected media clips can be utilized for effective development of learner awareness of such factors.

To this end, we are turning to the use of authentic materials in the next section. We will elaborate on our use of authentic materials in terms of lesson design, activities, and assessment methods, which will be preceded by a discussion of the theoretical background and methodology.

\section{Theoretical background and methodology}

This section provides an account of the theoretical backgrounds and methodological issues from which we draw implications for the design of this teaching unit. 
We adopt $\mathrm{Li}$ and Thompson's (1981) analysis of the utterance-final particle le with additional modifications. Li and Thompson (1981) propose that "the basic communicative function of le is to signal a 'Currently Relevant State' (abbreviated as CRS). What this means is that le claims that a state of affairs has special current relevance with respect to some particular situation' (Li and Thompson 1981: 240). Li and Thompson explain that the use of le "says that some state of affairs is current with respect to some particular situation. When no other situation is mentioned, then it is always assumed that the statement signaled by the sentence with the le is relevant to now."

In addition, Li and Thompson (1981: 244) point out that CRS can be broadly grouped into five categories if the state of affairs it represents:

1. Is a changed state

2. Corrects a wrong assumption

3. Reports progress so far

4. Determines what will happen next

5. Is the speaker's total contribution to the conversation at that point.

To our knowledge, this is the most useful characterization of the discourse functions of $l e$ in the existing studies. Yet there are some additional remarks we would like to make with regard to the characterization of le and the learning and teaching of $l e$ in an L2 context. First, the five categories identified by Li and Thompson as situations where le expresses CRS should not be taken as exhaustive or categorical; some of them may need to be expanded or refined while others may apply simultaneously in some situations. For example, our collection of authentic data shows that Category 2, "corrects a wrong assumption," may include less strong situations where something like a counter-expectation is described. This is illustrated by a video clip in which the mother shows up at a hospital where her son, a doctor, works, and the doctor starts with “妈, 你怎 么来了?” “Mom, why are you here?” In such a situation, the closest category that can be applied would be that of No. 2; however, "corrects a wrong assumption" may not be the best way to explain this use, hence the suggestion to augment the category. Moreover, sometimes multiple categories may need to be recognized as applicable to a single case. For example, there are instances in our data where both "reports progress so far" and "corrects a wrong assumption" or "describes a counter-expectation" are appropriate. We regard this not as an issue with the categorization but rather a fact of language use, and this has implications for language teaching and learning. That is, when we analyze and teach instances of $l e$ in authentic materials, it is entirely expected, and learners need to be aware of, that such cases of multiplicity do exist. 
Second, without the use of authentic materials that can clearly illustrate a concrete context (Tao 2005a), teachers may still find it rather abstract to explain le to students, and it is by no means always transparent to students either, especially when there may be L1 interferences, when the use of le would be called for: what exactly is a currently relevant situation? Aren't all utterances currently relevant? If not, why talk about it at this point? (This is actually a question that the first author was asked by an American English-speaking student when dealing with isolated sentences in a textbook). In fact, the acquisition study by Wen (1995) that adopts Li and Thompson's account reports how learners are often confused in their understanding of "currently relevant state". Finally, related to the second point is the fact that while $\mathrm{Li}$ and Thompson's analysis may represent linguists' viewpoint on language production, namely as analysis of materials produced by L1 speakers, for learners the most important task in engaging in dialogic communication is to make choices among an infinite number of potential forms in ways that resemble native-like selection (Pawley and Syder 1983: 193). Thus, we need to understand that for learners, the goal is not to distinguish between one category from another, but rather whether or not to use le and sometimes whether to apply one or multiple instances of le. To address this issue, we will strive to underscore the importance of exploring grammar through context in the design of activities and assessments throughout the teaching unit. In doing so, we hope that learners become more aware of the contextual factors that impact the choices and become more proficient in making the more appropriate choices.

The proposal that it is necessary to highlight the importance of contextual information in language teaching materials has been well argued and exemplified in the field. For English-based works, the reader is referred to McCarthy (1991), Carter et al. (2000), among others. For Chinese, Tao (2005a) provides compelling evidence that most constructed spoken texts lack naturalistic contextual information, and as a result, the language often appears to be unnatural. One of the solutions suggested by Tao (2005a) is to use context-based and context-oriented designs of teaching material to improve spoken Chinese language pedagogy. As will be seen later, this is achieved primarily through employing line-by-line commentaries as a way of explicit instruction and as a form of student exercise. As research (e.g., Su 2017) has demonstrated that our knowledge of grammar includes not only the use of a particular grammatical construction in a given context but also the non-use of it, in our teaching design, we will include an explanation of not only the uses of $l e$ but also the non-uses of it to help learners make informed linguistic choices.

Finally, we would like to discuss the use of media clips as teaching materials. Without any doubt, media clips are not of the highest degree of 
authenticity. McGinnis (1990), while suggesting (and we agree) the use of authentic materials such as movies in lower level language teaching, asks that "is something like a movie or play more valid as an educational tool simply by virtue of its being made by and produced for native speakers?" This question is indeed worth exploring. Different kinds of authentic materials possess different degrees of authenticity. Rings (1986) ranks the authenticity of conversational language materials into 16 different levels. Type 1, of the highest authenticity, is "native speakers' spontaneous conversations produced for their own conversation purposes (no knowledge of being monitored)." Type 2 is "conversations in which one participant is aware of being monitored or recorded.” The kind of recorded naturally-occurring everyday conversation that linguists/applied linguists use for research or language teaching belongs to this level. Non-scripted and basically non-edited spontaneous media products such as the Mandarin talk show Qiangqiang Sanrenxing 'Three Companions', according to this taxonomy, also belong to this rank. Entertainment forms such as movies and TV drama belong to Type 4, which refers to "plays written by a genius in language use and enacted by good actors/actresses." Type 16, the least authentic, is "composed conversations printed in textbooks." According to Rings' rankings, then, language recorded or filmed in media form is much more authentic than traditional construed textbook language. We believe that although media clips from sources such as movies and TV dramas are scripted and heavily edited, they still preserve the frequency information and discourse usage patterns that L1 speakers are exposed to when they acquire their L1 language (and as the adults' L1 language continues to be shaped by the discourse and language products they are exposed to). Of course, a distinct advantage of media clips is their visual effects, which can be a draw to the learner. Having noted this, we suggest that teachers keep in mind the limitations of media clips.

In what follows, we will provide teaching guides and materials that utilize authentic materials in entertainment video forms as well as the above-cited discourse functional findings to illustrate the usage of the utterance-final particle le.

\section{Objectives and proficiency level}

The teaching unit is divided into four parts. In each part, notes for teachers precede the actual materials. The unit is designed for students in a beginninglevel/first-year language class. This unit will require two 50-minute class 
sessions or one and a half 75-minute class sessions, with the understanding that this is but a general guideline to be adapted to local pedagogical conditions.

We outline the following objectives in response to the common errors that learners have been identified to make, as discussed earlier in Section 1.3, and the relevant communicative factors discussed in Section 2. Note that admittedly the objectives listed below may appear to be ambitious for the limited claimed classroom time, our goal is to show ways to help the learner to improve awareness, be able to start noticing contextual/communicative factors, and deploy le in a more effective manner. Hopefully, with repeated interactive teaching activities involving authentic materials, as we strive to illustrate here, learners will start to master the use (and non-use) of the forms in a proficient way. In consideration that the instruction is at the beginning level and that the use of le often involves various complex grammatical structures that the students might not have learned at the time when le is usually introduced, the following learning objectives do not aim for any unrealistic goals to master all these structures after merely two class sessions. The first step, which is rather important, is the ability to identify such uses in authentic materials and the communicative consequences of making such linguistic choices.

Learning Objectives:

(1) Distinguish utterance-final le2 from verb suffix le1.

(2) Identify at least one of the five manifestations of the communicative function of the utterance-final le in discourse.

(3) Use commonly observed "adverb + utterance-final le" structures to express information pertaining to the immediate future.

(4) Use the utterance-final le to express the change of a situation.

(5) Use verb phrases with a resultative complement + utterance-final le to emphasize the current relevance of the occurrence of an event.

(6) Use the utterance-final le to emphasize the current relevance of the occurrence of an event, with and without the use of an adverb yijing 'already' in the prompt.

\section{Instruction: Teaching materials and classroom activities}

The following four sections are designed to address the just stated six large-scale objectives in various ways, ranging from raising awareness (4.1), recognizing relevant factors in communicative situations (4.2), to various in-class practices (4.3) and exercise design (4.4). 


\subsection{Teaching guide I: Structural awareness}

The goal of this part is to raise the learners' awareness of the existence of the two types of le in Mandarin: the verb suffix le1 and the utterance-final particle le2 and situations where they may conflate in the same position. (Note that in the case of conflation of the two tokens of $l e$, no effort is made to distinguish exactly which one is involved as oftentimes both notions can be applied). This part addresses Objective (1).

An example sentence such as the following can be used to introduce the structural, semantic, and pragmatic distinctions between the two types. For the explanation of the verb suffix le1, this study adopts Liu M.’s (2015) finding that le1 indicates the realization of an action, meaning an action being realized in real time, which is more than a simple past as in English.

Step 1: Start with an example of both non-le and the verb suffix le1.

(1) Show students the following example (4):

\begin{tabular}{|l|l|l|}
\hline 1. 小男孩: 你们做了 & 1. Boy: What did you cook & 1. 小男孩:你們做了 \\
1什么? & (lit. make)? & 1什麼? \\
2. 给我看看。 & 2. Let me take a look. & 2. 給我看看。 \\
\hline
\end{tabular}

(2) Compare line 1 with line 2 and draw students' attention to the use of le1 in line 1 and the non-use of $l e$ in line 2.

(3) (.) Play the video clip, \#1 le1_What did you cook, three times.

(4) Go back to the example again and tell the students why le1 is used in line 1: The little boy sees that a dish was made; that is, the action of cooking this specific dish has been realized in real time. To ask about what dish the adult cooked, the little boy uses a verb suffix le1 to indicate that he is talking about a specific action that has been realized in real time and not about the action of cooking in general. So le1 signals the realization of an action. Also, use examples such as 你明天 到了就给我打电话 'Please give me a call upon your arrival tomorrow' to explain to the students that $l e 1$ is not the same as a past tense marker in languages such as English.

(5) Ask the students where le1 is placed within the sentence: is it after the verb or at the end of the sentence? Then discuss with students that le1 is used after a verb (as in line 1) or a verb complement (e.g., 见到了爸爸 jian dao le1 baba 'saw dad'). 
(6) Explain to the students why le1 is not used in line 2: because the little boy is making a request in which no realization of an action or completion of an action is involved. Therefore, le1 is not used.

Step 2: Use the following example (Figure 1; example 5) to introduce the utterance-final particle le2 and compare its structural position with that of the verb suffix $l e 1 .{ }^{1}$ Tell students that $l e 2$ is at the end of a sentence, although it can be followed by the question particle 吗 $m a$ or another utterance-final particle 吧 $b a$ that students may have learned at the beginning level.

(5)

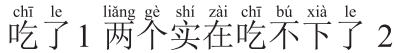
吃了1 兩個實在吃不下了 2
'(She) couldn't eat anymore after eating two (steamed buns).'

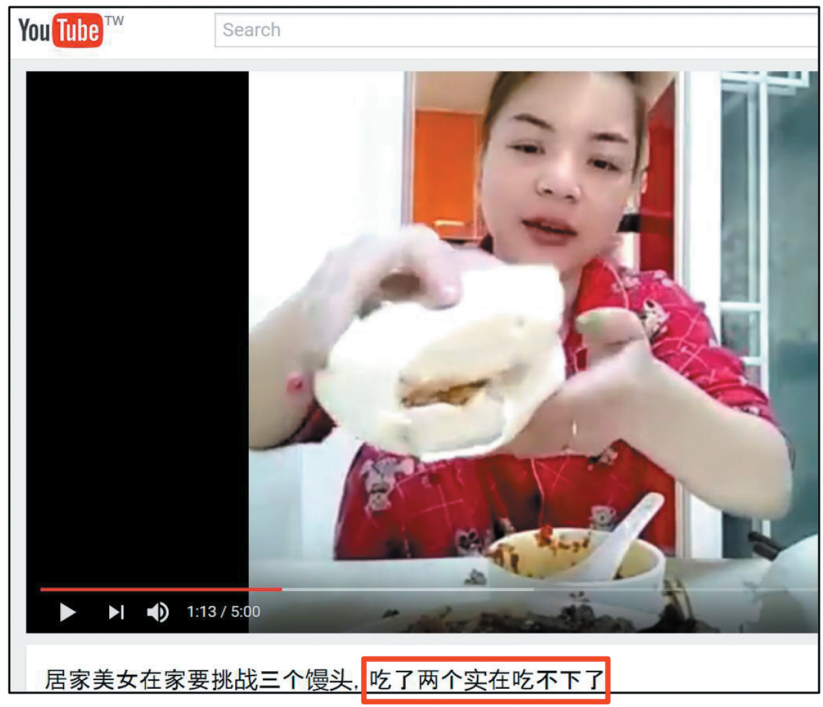

Figure 1: Structural positions of the verb suffix le1 and utterance-final particle le2.

Step 3: Use the following example (Figure 2; example 6) to explain to the students that sometimes the two types of le conflate in the same position when the verb that does not take any objects falls to the end of an utterance. It should be noted that in such cases the properties of the utterance-final le can still be applied.

1 While the associated YouTube video may not be entirely appropriate for the lesson, the instructor can nevertheless make use of it when teaching the title caption in (5). URL: https:// www.youtube.com/watch?v = RLBkKrAmFVU. 


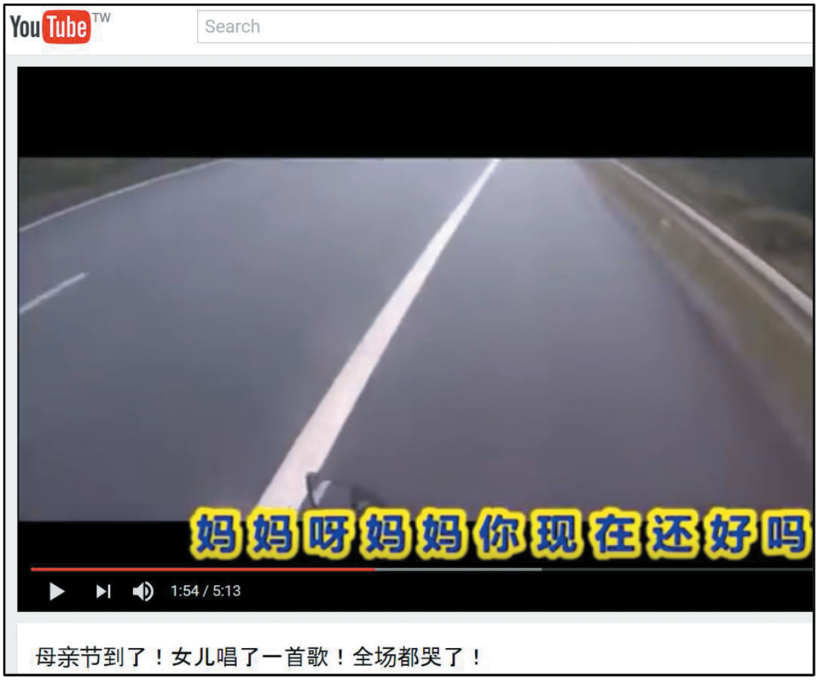

Figure 2: Two types of le conflate in the same position.

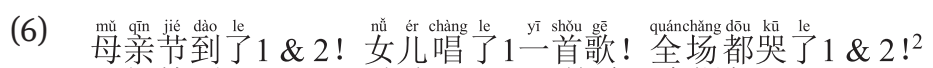

母親節到了 1 \& 2 ! 女兒唱了 1 一首歌! 全場都哭了 1 \& 2 !

'It's Mother's Day (lit. Mother's Day has arrived)! The daughter sang a song! The whole audience cried!'

Step 4: Exercises: Identifying the two types of $l e$.

The teacher can give exercises such as the following and ask students to indicate which le it is in each instance.

Examples:
（1）我昨天喝了_一杯咖啡。
（1）我昨天喝了——杯咖啡。
(2) 你上次已经请过我了_。
(2) 你上次已經請過我了_。
(3) 我病了_三天了_。
(3) 我病了—三天了—。
(4) 我病了—。
(4) 我病了—。

Answer keys:
（1）我昨天喝了 1 一杯咖啡。
(2) 你上次已经请过我了 2 。
（1）我昨天喝了 1 一杯咖啡。
(3) 我病了 1 三天了 2 。
(2) 你上次已經請過我了 2 。
(4) 我病了1 \& 2 。
(3) 我病了 1 三天了 2 。
(4) 我病了 1 \& 2 。

2 The URL for the song is https://www.youtube.com/watch?v=t_O7LeGuIuc. 
The instructor then tells the students that this lesson will primarily be concerned with the utterance-final particle le.

\subsection{Teaching guide II: Five scenarios of currently relevant state}

The goal of this part is to introduce the concept of "Currently Relevant State" (CRS) that the utterance-final le signals as well as the five possible manifestations. Note that the reason to focus on specific situations rather than simply apply an abstract label such as CRS or change of state in teaching is that general label may be convenient to apply, it is the specific manifestations that students will encounter in real life situations - occasions where various choices must be made. Note also that the original proposals in $\mathrm{Li}$ and Thompson (1981) may not be taken as exhaustive and static, and some augmentation may be made (for categories such as "corrects a wrong assumption”, as discussed earlier). This part addresses Objective (2).

Step 1: Play the video clip, \#2: le2_The notion of CRS, for an overview of what Currently Relevant State means.

Step 2: Play the video clip, \#3: le2_Five scenarios, for an overview of the five scenarios in which the use of the utterance-final le may be considered:

1. Is a changed state

2. Corrects a wrong assumption

3. Reports progress so far

4. Determines what will happen next

5. Is the speaker's total contribution to the conversation at that point

Step 3: Exercise: Use Figure 1 and Example (5) and ask the students to discuss the semantic and pragmatic differences between le1 and le2. Ask them how the meaning of "after (eating two)" is expressed (key: through the use of le1) and how the meaning of "anymore" is expressed (key: through the use of le2).

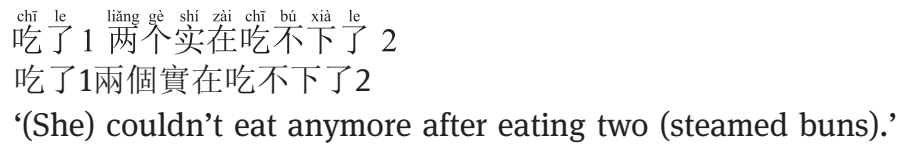

\subsection{Teaching guide III: Understanding currently relevant state through authentic materials}

The goal of this part is to illustrate some specific contexts where the particle le can be used, as well as contexts where it is not used. This part addresses Objectives (1), (2), (3), (5), and (6). 
Step 1: Tell the students that they are going to watch a video clip from a real TV show and they do not have to worry about completely understanding everything said there and that all they need to do at this point is to get an overall sense of what the video is about. Then plan to play the video clip, \#4: le2_You have already treated me last time, twice.

Step 2: Have the students study the transcript of this video clip (see "Detailed Transcript” in Appendix). Walk the students through the transcript. The focus of this step is on reading/script comprehension.

(1) Display the detailed transcript of video clip \#4 on a projected screen or give students a handout. Give the students a few seconds to read the "Description."

(2) Teach new vocabulary as necessary for understanding this teaching material.

(3) The teacher can first read each line in the transcript and ask the students to repeat.

(4) The teacher can then ask the students to read the lines in pair work.

(5) While displaying the transcript, \& play the sound of the video clip \#4 (without displaying the video) and point to the corresponding lines on the transcript for the students.

(6) While displaying the transcript, the teacher can ask a few questions (orally) to check the students' comprehension. For example,
i. 老余刚刚在哪里找这个女孩子? - 办公室。
ii. 女孩子的报告做完了吗? - 差不多了/快做完了。
iii. 老余今天晚上想要做什么? - 想请这个女孩子吃饭。
iv. 上次谁请谁吃饭? - 老余请女孩吃饭。
v. 今天晚上谁请谁吃饭? - 女孩请老余吃饭。

Step 3: Plan to play the video clip \#4 four times. The foci of this step are both on auditory comprehension and on oral production.

(1) For the first time, play the video without pause.

(2) The second time, pause after each sentence and have the students repeat the lines. Tell them to "take particular care to emulate the prosodic features of the speakers” (Tao 2011), especially the female speaker's refusal and request using la and le with lengthening and in high volume.

(3) The third time, play the video mute and ask the students to act out the roles and read the lines out loud in two-person pair work.

(4) The fourth time, play the video mute and have two student volunteers act out the roles and read the lines out loud.

Step 4: Go back to the transcript again (see "Brief Transcript" in Appendix). The foci of this step are on Objectives (1), (2), (3), (5), and (6). 
Objective (1): Distinguish utterance-final le2 from verb suffix le1.

For this purpose, ask the students to identify whether the tokens of le are the verb suffix $l e 1$ or the utterance-final particle le2. The students should be able to know that all the instances of $l e$ in this conversation are that of $l e 2$. After then, draw students' attention to line 3 “你报告做完了吗?” and tell them that the utterance-final particle le can be used with the question particle 吗 $m a$, in which case, the le proceeds the other particles.

Objective (2): Identify at least one of the five manifestations of the communicative function of the utterance-final le in discourse.

For this purpose, first, display or point to "Line-by-line Commentary."

Five scenarios of "Currently Relevant State" and potential expansions:

Scenarios 1. Is a changed state

Scenarios 2. Corrects a wrong assumption

Scenarios 3. Reports progress so far

Scenarios 4. Determines what will happen next

Scenarios 5. Is the speaker's total contribution to the conversation at that point

Then address the following questions for each line: Is there an instance of le2 here? If yes, why le2 is used here? In particular, how does it express "Currently Relevant State" and which scenario(s) does it belong to? Let the students know that there could be multiple scenarios in one case and that as long as they can identify at least one scenario to use le2, the purpose is served.

If not, why le2 is not applicable here, or what would have been communicated had it been used?

The dialogue takes place between a superior in a workplace ( $\mathrm{Yu}, \mathrm{male})$ and a subordinate (Girl).

\begin{tabular}{|c|c|c|}
\hline Lines & le2? & Line-by-line Commentary \\
\hline $\begin{array}{l}\text { 1. Girl: 老余? } \\
\mathrm{Yu}(\text { Lit. Old Yu)? }\end{array}$ & No & 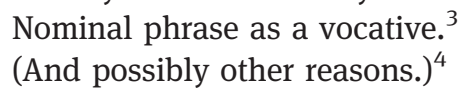 \\
\hline
\end{tabular}

3 Although le often does not follow a standalone nominal phrase, in certain registers, $\mathrm{NP}+l e 2$ is possible, as in 西单了Xidan le “(You've arrived/are arriving at the stop) Xidan." For a destination announcement in places as a public bus.

4 "Possible other reasons" throughout this paper means that sometimes multiple accounts, as discussed in this paper, can be applied but they are not exhaustively listed due to space constraints. 
2. $\mathrm{Yu}$ : 我刚刚在办公室 No 找你。

I was just looking for you at the office.

3. 你报告做完了吗? Yes Have you finished the report?

4. Girl: 差不多了, Yes Almost.

5. 我快做完了。 I am almost done.

Yes

6. $\mathrm{Yu}$ : 我就知道你可 以。

I know you can make it.

7. 晚上我请你吃个饭。 No (And possibly other reasons.)

8. Girl: 不要啦! No!

9. 你上次已经请过 Yes 我了。

You have already treated me last time.
Lack of le2 shows that the speaker is providing a simple description of what happened in the past ( $\mathrm{Li}$ and Thompson 1981: 293). If le2 were used here, which is possible, some pragmatic implications would have been communicated (e.g. blaming her disappearance). (And possibly other reasons.)

Scenarios 3. Reports progress so far. (And possibly other scenarios.)

Scenarios 3. Reports progress so far. (And possibly other scenarios.)

Scenarios 3. Reports progress so far. (And possibly other scenarios.)

No Normally, le2 is not used when asserting a general truth where no change is involved (Li and Thompson 1981: 291). (And possibly other reasons.)

Normally, le2 is not used when expressing an event or situation in the future, requests, suggestions, and commands (Li and Thompson 1981: 294). I want to treat you to dinner tonight.

Some believe that $l a$ 啦 is a fusion of $l e$ and $a$, or a regional/gender variation of le 2 in cases like this, which serves to reduce the forcefulness of the utterance. In this case, it indicates a polite refusal to an offer. (And possibly other reasons.)

Scenarios 4. Determines what will happen next (often appearing as an account to a suggestion expressed in the next utterance). (And possibly other scenarios.) 
10. 这次我请你。

It's my treat this time.

11. Yu: 好啊!

Okay!
No

This is a suggestion/proposal based on the account given earlier. Normally, le2 is not used when expressing an event or situation in the future, requests, suggestions, and commands (Li and Thompson 1981: 294). (And possibly other reasons.)

No 好啊 is a standalone fixed phrase for accepting an invitation/request/ suggestion without reluctance. (And possibly other reasons.)

Explain to the students that le typically does not go with the negator没 mei to describe past events (in fact * 没 + Verb $+了$ is often ungrammatical ${ }^{5}$ ).

Finally, tell students that multiple scenarios may be found in one instance of the utterance-final $l e$, but as long as students can detect one scenario and use le, the purpose is served.

Objective (3): Use commonly observed "adverb + verb/adj + utterance-final le" structures to express information pertaining to the immediate future.

Focus on line 5 我快做完了 and highlight the structure here:

$$
\begin{gathered}
\text { 快(要) }+ \text { /就要 + verb (phrase)/adjective +了 } \\
\text { 'About to ...' }
\end{gathered}
$$

Based on the students' level, give relevant and comprehensive examples to enhance students' understanding of this phrase. Sample examples:

电影就要开始了。

圣诞节快到了。

饭快好了。

Objective (5): Use verb phrases with a resultative complement + utterance-final le to emphasize the current relevance of the occurrence of an event.

Focus on line 5 做完了 and highlight the structure here:

$$
\begin{gathered}
\text { Verb + resultative complement }+l e \\
\text { 做 } \\
\text { 'finish doing something' }
\end{gathered}
$$

5 Except 没有了 mei you le2, which does not denote a past event. 
Based on the students' level, give relevant and comprehensible examples to illustrate the structure. Sample examples: 写好了、听清楚了、看完了、 学会了、听懂了、找到了.

Then give further examples to explain how the utterance-final le emphasizes the current relevance of the occurrence of an event. Sample examples:

- 老师: 小考写好了吗?

- 学生: 写好了。

- 老师: 好, 请大家交上来。

Objective (6): Use the utterance-final le to emphasize the current relevance of the occurrence of an event, with and without the use of an adverb yijing 'already' in the prompt.

Focus on line 9 你上次已经请过我了 and tell the student that without 已经 yijing 'already' the sentence 你上次请过我了 is still grammatical and still sounds natural, as long as le is used. The use of both yijing and le reinforces the sense of current relevance.

Based on the students' level, give relevant and comprehensible examples to enhance students' understanding of this point. Sample examples:

他已经病了三天了 and 他病了三天了。

我很喜欢那件衣服, 可是我的钱已经用完了 and 可是我的钱用完了。

Finally, tell students that besides these commonly seen patterns (快... 了、已经... 了), there are some other fixed expressions that often contain le, such as:

太 + verb/adj + 了 (e.g., 太好了! 'Great!')

好了. 'done/finished; enough(e.g., stop talking)'

算了. 'Never mind.'

\subsection{Teaching guide IV: Exercise with authentic materials}

The goal of this part is to provide an opportunity for students to work on authentic materials and practice the use and non-use of utterance-final le. This part addresses Objectives (1), (2), (3), (4), (5), and (6).

Step 1: Go over any new vocabulary items pertaining to the students' level.

Step 2: Students work in pairs or groups to determine whether a le can be used in a given utterance. 
The dialog takes place between two former lovers.

了 or no了?

1. Girl: 什么意思啊__ ?

2. Man: 答应你的我做到

3. 我自由

4. Girl: 所以 呢__ ?

5. Man: 回到我身边

6. 嫁给我吧

7. Girl: 我们不可能

8. Man: 还在生我的气

9. 继续惩罚我_?

10. 还是别的什么原因

11. Girl: 因为我要结婚

12. Man: 你要结婚 ?!

1. What do you mean? 1. Girl: 什麼意思啊__?

了 or no 了?

2. I have done what I 2. Man: 答應你的我做到 promised you.

3. I'm single again (lit. 3. 我自由_。

I'm free now)

4. So what?

5. Come back to me.

6. Marry me. ?

7. There's no way we can be (together).

8. You're still mad at me?

9. Are you still punishing me?

10. Or is there another reason?

11. Because I'm getting married.

12. You are getting married?!
4. Girl: 所以呢_?

5. Man: 回到我身邊—,

6. 嫁給我吧

7. Girl: 我們不可能

8. Man: 還在生我的氣

9. 繼續懲罰我—?

10. 還是別的什麼原因

11. $\overline{\text { Girl: }}$ ? 因為我要結婚

12. $\overline{\mathrm{Man}}$ : 你要結婚__?!

Step 3: $\odot$ Play the film clip of this conversational exchange (video clip \#5 le2_-I'm single again -- So what) and ask students to check their answers.

Step 4: Display the transcript of video clip \#5. Ask students to read them out loud either together or in pair role-play or individually.

1. Girl: 什么意思啊? 1. What do you mean?

2. Man: 答应你的我做 到了。

3. 我自由了。

4. Girl: 所以呢?

5. Man: 回到我身边,

6. 嫁给我吧。

7. Girl: 我们不可能了。

\section{I have done what I} promised you.

3. I'm single again (lit. I'm free 3. now)

4. So what?

5. Come back to me.

6. Marry me.

7. There's no way we can be (together) anymore.
1. Girl: 什麼意思啊?

2. Man: 答應你的我做 到了。 我自由了。

4. Girl: 所以呢?

5. Man: 回到我身邊,

6. 嫁給我吧。

7. Girl: 我們不可能了。 
8. Man: 还在生我的 气?

9. 继续惩罚我?

10. 还是别的什么原 因?

11. Girl: 因为我要结婚 了。

12. Man: 你要结婚?!
8. You're still mad at me?

9. Are you still punishing me?

10. Or is there another reason?

11. Because I'm getting married.

12. You are getting married?!
8. Man: 還在生我的

氣?

9. 繼續懲罰我?

10. 還是別的什麼原

因?

11. Girl: 因為我要結婚 了。

12. Man: 你要結婚?!

For Objectives (1), ask students to determine whether the tokens of le here are le1, le2, or both.

Step 5: For Objectives (2), (3), (4), (5), and (6), have students work in groups to discuss the use and non-use of the utterance-final le in each line. Let the students know that there could be multiple scenarios in one case and that as long as they could identify at least one scenario to use the utterance-final le, the purpose is served.

\begin{tabular}{|l|l|l|}
\hline Lines & le2? & Line-by-line Commentary \\
\hline $\begin{array}{l}\text { 1. Girl: 什么意思啊? } \\
\text { What do you mean? }\end{array}$ & & \\
\hline $\begin{array}{l}\text { 2. Man: 答应你的我做到了。 } \\
\text { I have done what I promised you. }\end{array}$ & & \\
\hline $\begin{array}{l}\text { 3. 我自由了。 } \\
\text { I'm single again (lit. I'm free now) }\end{array}$ & & \\
\hline $\begin{array}{l}\text { 4. Girl: 所以呢? } \\
\text { So what? }\end{array}$ & & \\
\hline $\begin{array}{l}\text { 5. Man: 回到我身边, } \\
\text { Come back to me. }\end{array}$ & & \\
\hline $\begin{array}{l}\text { 6. 嫁给我吧。 } \\
\text { Marry me. }\end{array}$ & & \\
\hline $\begin{array}{l}\text { 7. Girl: 我们不可能了。 } \\
\text { There's no way we can be (together) } \\
\text { anymore. }\end{array}$ & \\
\hline
\end{tabular}




\begin{tabular}{|l|l|l|}
\hline $\begin{array}{l}\text { 8. Man: 还在生我的气? } \\
\text { You're still mad at me? }\end{array}$ & & \\
\hline $\begin{array}{l}\text { 9. 继续惩罚我? } \\
\text { Are you still punishing me? }\end{array}$ & & \\
\hline $\begin{array}{l}\text { 10. 还是别的什么原因? } \\
\text { Or is there another reason? }\end{array}$ & & \\
\hline $\begin{array}{l}\text { 11. Girl: 因为我要结婚了。 } \\
\text { Because I'm getting married. }\end{array}$ & & \\
\hline $\begin{array}{l}\text { 12. Man: 你要结婚?! } \\
\text { You are getting married?! }\end{array}$ & & \\
\hline
\end{tabular}

(Sample answers:)

\begin{tabular}{|l|l|l|}
\hline Lines & le2? & Line-by-line Commentary \\
\hline $\begin{array}{l}\text { 1. Girl: 什么意思啊? } \\
\text { What do you mean? }\end{array}$ & No & $\begin{array}{l}\text { Simple nominal question. } \\
\text { (And possibly other reasons.) }\end{array}$ \\
\hline $\begin{array}{l}\text { 2. Man: 答应你的我做到了。 } \\
\text { I have done what I promised } \\
\text { you. }\end{array}$ & Yes & $\begin{array}{l}\text { Scenarios 1. Is a changed state } \\
\text { Scenarios 3. Reports progress so far } \\
\text { Scenarios 4. Determines what will hap- } \\
\text { pen next } \\
\text { (And possibly other scenarios.) }\end{array}$ \\
\hline $\begin{array}{l}\text { 3. 我自由了。 } \\
\text { I'm single again (lit. I'm free } \\
\text { now) }\end{array}$ & Yes & $\begin{array}{l}\text { Scenarios 1. Is a changed state } \\
\text { Scenarios 4. Determines what will hap- } \\
\text { pen next } \\
\text { (And possibly other scenarios.) }\end{array}$ \\
\hline $\begin{array}{l}\text { 4. Girl: 所以呢? } \\
\text { So what? }\end{array}$ & No & $\begin{array}{l}\text { 所以呢 is a standalone fixed expression } \\
\text { that has a similar meaning to the English } \\
\text { expression So what? } \\
\text { (And possibly other reasons.) }\end{array}$ \\
\hline $\begin{array}{l}\text { 5. Man: 回到我身边, } \\
\text { Come back to me. } \\
\text { Marry me. }\end{array}$ & No & $\begin{array}{l}\text { Le2 is not used when making a request } \\
\text { (Li and Thompson 1981: 294). }\end{array}$ \\
\hline
\end{tabular}




\begin{tabular}{|l|l|l|}
\hline $\begin{array}{l}\text { 7. Girl: 我们不可能了。 } \\
\text { There's no way we can be } \\
\text { (together) any more. }\end{array}$ & Yes & $\begin{array}{l}\text { Scenarios 1. Is a changed state } \\
\text { (And possibly other scenarios.) }\end{array}$ \\
\hline $\begin{array}{l}\text { 8. Man: 还在生我的气? } \\
\text { You're still mad at me? }\end{array}$ & No & $\begin{array}{l}\text { Le2 is not used when describing an } \\
\text { ongoing state. }\end{array}$ \\
\hline $\begin{array}{l}\text { 9. 继续惩罚我? } \\
\text { Are you still punishing me? }\end{array}$ & No & $\begin{array}{l}\text { Le2 is not used when describing an } \\
\text { ongoing action. }\end{array}$ \\
\hline $\begin{array}{l}\text { 10. 还是别的什么原因? } \\
\text { Or is there another reason? }\end{array}$ & No & $\begin{array}{l}\text { Simple nominal question. } \\
\text { (And possibly other reasons.) }\end{array}$ \\
\hline $\begin{array}{l}\text { 11. Girl: 因为我要结婚了。 } \\
\text { Because I'm getting married. }\end{array}$ & Yes & $\begin{array}{l}\text { Scenarios 4. Determines what will hap- } \\
\text { pen next (often appearing as an account } \\
\text { to a suggestion expressed in the next } \\
\text { utterance). } \\
\text { (And possibly other scenarios.) }\end{array}$ \\
\hline $\begin{array}{l}\text { 12. Man: 你要结婚?! } \\
\text { You are getting married?! }\end{array}$ & No & $\begin{array}{l}\text { Either use or non-use le2 is grammatical } \\
\text { here. However, repetition without le } \\
\text { serves to highlight the part from the pre- } \\
\text { vious speaker that the current speaker } \\
\text { finds most unbelievable. }\end{array}$ \\
\hline
\end{tabular}

Step 6: For Objective (4) "Identify the use of the utterance-final le to express a change of a situation”, draw students' attention to line 3 我自由了 and have students volunteer to answer why the le signals a change of state here.

\section{Assessment}

\subsection{Assessment part I: Working with authentic materials}

For this assessment, the teacher may use $\odot$ video clip \#6 le2_You haven't come home for three days, the transcript, and the following sample test questions.

Transcript
1. 品中:妈,
1. Pinzhong: Mom,
1. 品中:媽,
2. 妈妈:品中,
2. Mother: Pinzhong,
2. 媽媽:品中, 
3. 品中: 你怎么来 了?

4. 妈妈: 你三天没回 家了,

5. 我当然过来看一 看。

6. 还没醒过来啊?

7. 医生怎么说?

8. 品中: 许医生说,

9. 护士: 罗先生,

10. 不好意思，
3. Pinzhong: How come you are here?

4. Mother: You haven't come home for three days.

5. Of course, I would come and check it out.

6. She still hasn't woken up?

7. What did the doctor say?

8. Pinzhong: Doctor $\mathrm{Xu}$ said,

9. Nurse: Mr. Luo,

10. excuse me.
3. 品中: 你怎麼來 了?

4. 媽媽: 你三天沒回 家了,

5. 我當然過來看一 看。

6. 還沒醒過來啊?

7. 醫生怎麼說?

8. 品中: 許醫生說,

9. 護士: 羅先生,

10. 不好意思,

11. 503 的病人醒了。11. The patient in 503 has woken up. 11.503 的病人醒了。

Sample question \#1: Which kind of le can be observed here: verb suffix le1 or utterance-final particle le2, or both?

1. 品中: 妈,

2. 妈妈: 品中,

3. 品中: 你怎么来了?

4. 妈妈: 你三天没回家了,

5. 我当然过来看一看。

6. 还没醒过来啊?

7. 医生怎么说?

8. 品中: 许医生说,

9. 护士: 罗先生,

10. 不好意思，

11. 503 的病人醒了。
1. 品中: 媽,

2. 媽媽: 品中,

3. 品中: 你怎麼來了?

4. 媽媽: 你三天沒回家了,

5. 我當然過來看一看。

6. 還沒醒過來啊?

7. 醫生怎麼說?

8. 品中: 許醫生說,

9. 護士：羅先生,

10. 不好意思,

11. 503 的病人醒了。

Answer key:

Line 3: 了1 \& 2

Line 4: 了2

Line 11: 了1 \& 2

Sample questions \#2: Why the use and non-use of the utterance-final le?

Five scenarios of "Currently Relevant State":

Scenarios 1 . Is a changed state

Scenarios 2. Corrects a wrong assumption or counter-expectations

Scenarios 3. Reports progress so far

Scenarios 4. Determines what will happen next

Scenarios 5. Is the speaker's total contribution to the conversation at that point 
Note that there could be multiple scenarios in one case. As long as you can identify at least one scenario to use the utterance-final $l e$, the purpose is served.

\begin{tabular}{|l|l|l|}
\hline Lines & le2? & Line-by-line Commentary \\
\hline $\begin{array}{l}\text { 1. 品中: 妈, } \\
\text { Mom, }\end{array}$ & & \\
\hline $\begin{array}{l}\text { 2. 妈妈: 品中, } \\
\text { Pinzhong, }\end{array}$ & & \\
\hline $\begin{array}{l}\text { 3. 品中: 你怎么来了? } \\
\text { How come you are here? }\end{array}$ & & \\
\hline $\begin{array}{l}\text { 4. 妈妈: 你三天没回家了, } \\
\text { You haven't come home for three days. }\end{array}$ & & \\
\hline $\begin{array}{l}\text { 5. 我当然过来看一看。 } \\
\text { Of course I would come and check it out. }\end{array}$ & & \\
\hline $\begin{array}{l}\text { 6. 还没醒过来啊? } \\
\text { She still hasn't woken up? }\end{array}$ & & \\
\hline $\begin{array}{l}\text { 7. 医生怎么说? } \\
\text { What did the doctor say? }\end{array}$ & & \\
\hline $\begin{array}{l}\text { 8. 品中: 许医生说, } \\
\text { Doctor Xu said, }\end{array}$ & & \\
\hline $\begin{array}{l}\text { 9. 护士: 罗先生, } \\
\text { Mr. Luo, }\end{array}$ & & \\
\hline $\begin{array}{l}\text { 10. 不好意思, } \\
\text { excuse me. }\end{array}$ & \\
\hline $\begin{array}{l}\text { 11. } 503 \text { 的病人醒了。 } \\
\text { The patient in 503 has woken up. }\end{array}$ & \\
\hline
\end{tabular}

(Sample answers:)

\begin{tabular}{|l|l|l|}
\hline Lines & le2? & Line-by-line Commentary \\
\hline 1. 品中: 妈, & No & $\begin{array}{l}\text { Nominal phrase as a vocative. } \\
\text { (And possibly other reasons.) }\end{array}$ \\
\hline
\end{tabular}




\begin{tabular}{|c|c|c|}
\hline 2. 妈妈: 品中, & No & $\begin{array}{l}\text { Nominal phrase as a vocative. } \\
\text { (And possibly other reasons.) }\end{array}$ \\
\hline $\begin{array}{l}\text { 3. 品中: 你怎么 } \\
\text { 来了? }\end{array}$ & Yes & $\begin{array}{l}\text { Scenarios } 2 \text {. Corrects a wrong assumption or indi- } \\
\text { cating a counter-expectation. } \\
\text { (And possibly other scenarios.) }\end{array}$ \\
\hline $\begin{array}{l}\text { 4. 妈妈: 你三天 } \\
\text { 没回家了, }\end{array}$ & Yes & $\begin{array}{l}\text { Scenarios 3. Reports progress so far and indicates a } \\
\text { counter-expectation. This can also be seen as } \\
\text { Scenario \#4: determines what will happen next } \\
\text { (often appearing as an account of a follow-up } \\
\text { action expressed in the next utterance). } \\
\text { (And possibly other scenarios.) }\end{array}$ \\
\hline $\begin{array}{l}\text { 5. 我当然过来看 } \\
\text { 一看。 }\end{array}$ & No & $\begin{array}{l}\text { This is a follow-up action based on the account } \\
\text { given earlier. Le2 is not used when describing a } \\
\text { follow-up action. } \\
\text { (And possibly other reasons.) }\end{array}$ \\
\hline $\begin{array}{l}\text { 6. 还没醒过来 } \\
\text { 啊? }\end{array}$ & No & $\begin{array}{l}\text { Le typically does not go with the negation 没 mei. } \\
\text { (And possibly other reasons.) }\end{array}$ \\
\hline 7. 医生怎么说? & No & $\begin{array}{l}\text { Le2 is not used in a simple description of an event } \\
\text { that happened in the past. In this case, a question } \\
\text { is raised as to the manner or content of a speech. } \\
\text { (And possibly other reasons.) }\end{array}$ \\
\hline $\begin{array}{l}\text { 8. 品中: 许医生 } \\
\text { 说, }\end{array}$ & No & $\begin{array}{l}\text { Le2 is not used in a simple assertion of an event that } \\
\text { happened in the past. This is especially the case } \\
\text { when the prior utterance asks about what Doctor } \\
\mathrm{Xu} \text { has said, not whether or not the doctor has } \\
\text { said anything, which would call for a token of le2. } \\
\text { (And possibly other reasons.) }\end{array}$ \\
\hline $\begin{array}{l}\text { 9. 护士: 罗先 } \\
\text { 生, }\end{array}$ & No & $\begin{array}{l}\text { Nominal phrase as a vocative. } \\
\text { (And possibly other reasons.) }\end{array}$ \\
\hline 10. 不好意思, & No & $\begin{array}{l}\text { 不好意思 is a standalone fixed phrase for apologizing. } \\
\text { (And possibly other reasons.) }\end{array}$ \\
\hline $\begin{array}{l}\text { 11. } 503 \text { 的病人醒 } \\
\text { 了。 }\end{array}$ & Yes & $\begin{array}{l}\text { Scenarios } 2 \text { and } 4 \text {. Indicates a changed state and } \\
\text { determines what will happen next. } \\
\text { (And possibly other scenarios.) }\end{array}$ \\
\hline
\end{tabular}




\subsection{Assessment part II: Focusing on language patterns}

Sample questions \#1: Fill in the blank in the following examples.

(Note: The questions below need to be revised according to students' actual level.)

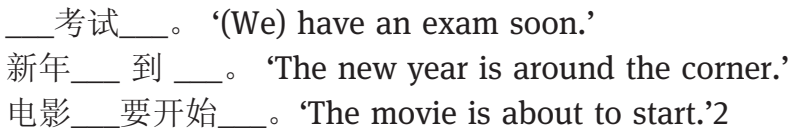

Answer key: 快/就要考试了。新年快/就要到了。电影快/就要开始了。

Sample questions \#2: How to say with le?

1. If you want to indicate that you have finished writing (写好/完) your homework, you may say

功课我

2. If you want to indicate that you have understood (听懂) what the teacher said, you may say 老师的话我

3. If you want to indicate that you have finished reading (看完) a particular book, you may say 这本书我

4. If you want to indicate that you have learned (学会) a particular grammatical structure, you may say

5. If you want to indicate that you have found (找到) your lost textbook, you may say

6. If you want to indicate that you have NOT yet started preparing (准备) for the exam next week, you may say

Answer key:

1. 功课我写好/完了。

2. 这节课我听懂了。

3. 这本书我看完了。

4. 这个语法我学会了。

5. 课本找到了。

6. 下周的考试我还没开始准备。 


\subsection{Assessment part III: Putting to use}

For this part, we suggest that teachers who have the instructional time and support give one-on-one individual conversational tests for each student to assess students' interactional competence regarding the use of the utterancefinal particle le.

Sample questions to ask during the conversational test are:

1. Have you understood the materials covered in our last Chinese class meeting? 昨天/上个星期/...的中文课你听懂了吗?

2. Have you previewed Lesson $\mathrm{X}$ (the following lesson that the teacher has not yet taught)?

第X课你预习了吗?

(The student should not use the utterance-final $l e$ for 还没 but should use it if already previewed: 预习 (好) 了。

3. Have you finished doing the last homework assignment? 昨天/上个星期/...的功课你做完了吗?

4. Have you started preparing for the final exam? 期末考你开始准备了吗?

5. Tell me something about recent changes in your life, such as a new skill you have learned, a change in your personal preferences (such as dietary and exercise). (Note that this could also be designed as an in-class exercise in the form of pair or group work where students discuss each other's use of the utterance-final $l e$ and get credits for doing this.)

\section{Conclusions}

As a notoriously difficult grammatical feature of Chinese, le2 has proven to be a challenge for learners. We tackled this issue with entertainment video clips in movies, TV shows, and internet video. We emphasized in this teaching unit the contexts in which this utterance-final particle is used and how speakers use it to achieve discourse-pragmatic goals. To provide a more comprehensive understanding of how le works, we focused on not only the use of this particle but also the non-use of it in a given context. We believe that teachers of Chinese can benefit from a view of the intertwined relationship between context, function, and structure, and it is hoped that the 
arguments provided in this paper help broaden such a view. At the same time, our unit design focuses on raising awareness of a number of important issues associated with le, e.g. the two types of le (Section 4.1) and the relevant factors in communicative situations where le is called for (Section 4.2). We also demonstrate how to use authentic materials for in-class instructions and practices (Section 4.3), and how exercises may be designed to reinforce the understanding of the relevant features (Section 4.4). Finally, Section 5 also demonstrates ways to design assessment tools to evaluate learners' mastery of discourse-pragmatic competence - again through the use of authentic materials and communicative activities. Recognizing the complexity of the issue at hand and the diverse local teaching parameters, we hope that the overall framework and sample designs provided here can serve as a starting point for further elaboration and modification to serve the needs of individual teaching and learning settings.

\section{Appendix}

All relevant video clips used in this article can be found from this website: http://clicresearch.rice.edu/caslar-authentic-spoken-language/\#le

Transcript of video clip \#4 You have already treated me last time

(Video Source: 小資女孩向前衝 Day9 我喜歡沈杏仁? https://www.youtube. com/watch?v = Lx2rpiHIN7w)

1. Vocabulary:

\begin{tabular}{llll}
\hline 刚 & 剛 & gāng & just \\
办公室 & 辦公室 & bàngōngshì & office \\
找 & 找 & zhào & to look for \\
报告 & 報告 & bàogào & report \\
差不多 & 差不多 & chàbudūo & almost \\
知道 & 知道 & zhīdao & to know \\
已经 & 已經 & y̌̀jīng & already \\
\hline
\end{tabular}

2. Description: $\mathrm{Yu}$ is a senior co-worker of the girl. The two are friends too. $\mathrm{Yu}$ finds the girl in the lounge of their company and wants to treat her to dinner again. However, the girl suggests that it should be her treat this time around because it was Yu's treat last time. 


\section{Detailed Transcript:}

\begin{tabular}{|c|c|c|c|}
\hline & lăoyú & 1. Girl: $\mathrm{Yu}$ (Lit. Old Yu)? & lăoyú \\
\hline 1. Girl: & $\begin{array}{l}\text { : 老余? } \\
\text { wōgānggāngzài }\end{array}$ & $\begin{array}{l}\text { 2. } \mathrm{Yu} \text { : I was just looking } \\
\text { for you at the office. } \\
\text { 3. Have you finished the }\end{array}$ & $\begin{array}{l}\text { 1. Girl: 老余? } \\
\text { wǒgānggāng }\end{array}$ \\
\hline 2. Yu: & $\begin{array}{l}\text { 我 刚刚 在 } \\
\text { bàngōngshìzhăo nǐ }\end{array}$ & $\begin{array}{l}\text { 3. Have you finished the } \\
\text { report? } \\
\text { 4. Girl: Almost. }\end{array}$ & $\begin{array}{l}\text { 2. Yu: 我 剛 剛 } \\
\text { zàibàngōngshìzhăo nĩ }\end{array}$ \\
\hline & $\begin{array}{l}\text { 办公室 找 你。 } \\
\text { nǐbàogàozuoòwán le ma }\end{array}$ & $\begin{array}{l}\text { 5. I am almost done. } \\
\text { 6. Yu: II know you } \\
\text { can make it. }\end{array}$ & $\begin{array}{l}\text { 在辦 公 室 找你。 } \\
\text { nǐbàogàozuòwán le má }\end{array}$ \\
\hline 3. & $\begin{array}{l}\text { 你 报告 做 完了吗? } \\
\text { chàbuduō le }\end{array}$ & $\begin{array}{l}\text { 7. I want to treat you to } \\
\text { dinner tonight. }\end{array}$ & $\begin{array}{l}\text { 你報告 做 完了嗎? } \\
\text { chàbuduō le }\end{array}$ \\
\hline 4. Girl: & $\begin{array}{l}\text { : 差不多了， } \\
\text { wǒkuàizuòwán le }\end{array}$ & $\begin{array}{l}\text { 9. You have already treated } \\
\text { me last time. }\end{array}$ & $\begin{array}{l}\text { 4. Girl: 差不多了， } \\
\text { wǒkuàizuòwán le }\end{array}$ \\
\hline 5. & $\begin{array}{l}\text { 我 快 做 完了。 } \\
\text { wǒjiùzhīdao nǐ kěyĩ }\end{array}$ & $\begin{array}{l}\text { 10. It's my treat this time. } \\
\text { 11. Yu: Okay! }\end{array}$ & $\begin{array}{l}\text { 我 快 做 完了。 } \\
\text { wǒjiùzhīdao nǐ kěyǐ }\end{array}$ \\
\hline 6. Yu: & $\begin{array}{l}\text { 我就 知道 你可以。 } \\
\text { wănshangwǒqǔngnĭ chīgè fàn }\end{array}$ & & $\begin{array}{l}\text { 6. Yu: 我就 知道你可以。 } \\
\text { wănshangwǒqǔng nǐ chīgěfàn }\end{array}$ \\
\hline 7. & $\begin{array}{l}\text { 晚上 我请 你吃个饭。 } \\
\text { búyàola }\end{array}$ & & $\begin{array}{l}\text { 晚上 我 請你吃個飯。 } \\
\text { búyàola }\end{array}$ \\
\hline 8. Girl: & $\begin{array}{l}\text { : 不要 啦! } \\
\text { nǐ shàngcìy̌jīngqungguòwǒle }\end{array}$ & & $\begin{array}{l}\text { 8. Girl: 不要啦! } \\
\text { nǐ shàngcì yí jīngqunngguōwǒ le }\end{array}$ \\
\hline 9. & $\begin{array}{l}\text { 你上次 已经请 过 我了。 } \\
\text { zhècì wǒqǔngnî }\end{array}$ & & $\begin{array}{l}\text { 你上次已經 請 過 我了。 } \\
\text { zhè cì wǒqung nǐ }\end{array}$ \\
\hline 10. & $\begin{array}{l}\text { 这次我请 你。 } \\
\text { hăoa }\end{array}$ & & $\begin{array}{l}\text { 這次我 請 你。 } \\
\text { hăo a }\end{array}$ \\
\hline 11. Yu: & : 好 啊! & & 11. Yu：好啊! \\
\hline
\end{tabular}

\section{References}

Carter, Ronald \& Michael McCarthy. 1997. Exploring spoken English. Cambridge: Cambridge University Press.

Carter, Ronald, Rebecca Hughes, \& Michael McCarthy. 2000. Exploring grammar in context: Grammar reference and practice, upper-intermediate and advanced. Cambridge: Cambridge University Press.

Chan, Marjorie K. M. 1980. Temporal reference in Mandarin Chinese: An analytical-semantic approach to the study of the morphemes le, zai, zhe and ne. Journal of the Chinese Language Teachers Association 15(3). 33-79.

Chao, Yuen Ren. 1968. A grammar of spoken Chinese, Berkeley: University of California Press.

Chen, Chien-Chou. 2009. Ambiguity of $l e$ in Chinese: The perfective as well as imperfective. Journal of Chinese Linguistics 37(1). 108-129.

Ding, Chongming (丁崇明). 2012. 外国学生“了”习得考察及相关问题研究 [Foreign students” acquisition of Chinese “le” and related issues]. 云南师范大学学报(对外汉语教学与研究版) 
[Journal of Yunnan Normal University(Teaching and Research on Chinese as a Foreign Language)] 10(4). 1-8.

Ellis, Rod. 1994. The study of second language acquisition. Oxford: Oxford University Press. Gilmore, Alex. 2007. Authentic materials and authenticity in foreign language learning. Language Teaching 40(2). 97-118.

Gilmore, Alex. 2011. “I prefer not text”: Developing Japanese learners' communicative competence with authentic materials. Language Learning 61(3). 786-819.

Li, Charles N. \& Sandra A. Thompson. 1981. Mandarin Chinese: A functional reference grammar. Berkeley: University of California Press.

Liu, Hanwu (刘汉武) \& Chongming Ding (丁崇明). 2015. 汉语“了”在越南语中的对应形式及母语 环境下越南初级汉语学习者“了”的习得 [The corresponding forms of le in Vietnamese and the acquisition of elementary learners in native language environment]. 语言教学与研究 [Language Teaching and Linguistic Studies] 174(4). 25-32.

Liu, Meichun. 2015. Tense and aspect in Mandarin Chinese. In William S-Y. Wang \& Chaofen Sun (eds.). The Oxford Handbook of Chinese Linguistics, 274-289. New York: Oxford University Press.

Liu, Yi (刘艺). 2015. 汉语学习者“了2”陈述句语调音高的习得分析 [The intonation acquisition of Chinese declarative sentences with modal particle “le” by learners]. 汉语学习[Chinese Language Learning] (4). 76-84.

Liu, Yuehua, Tao-chung Yao, Nyan-Ping Bi, Liangyan Ge, \& Yaohua Shi. 2009. Integrated Chinese (Level 1, Part 1) (Third Edition), Boston: Cheng \& Tsui Company.

McCarthy, Michael. 1991. Discourse analysis for language teachers. Cambridge: Cambridge University Press.

McGinnis, Scott Gary. 1990. A pragmatic analysis of Mandarin interrogatives: Data from modern Taiwan drama. Doctoral dissertation. Columbus, $\mathrm{OH}$ : The Ohio State University.

Mishan, Freda. 2005. Designing authenticity into language learning materials. Bristol: Intellect.

Nunan, David. 1989. Designing tasks for the communicative classroom. Cambridge: Cambridge University Press.

Pawley, A. \& Snyder, Francis H. 1983. Two puzzles for linguistic theory. In J. Richards \& R. Smith (eds.). Language and communication, 192-226. New York: Longman.

Pinner, Richard. 2013. Authenticity of Purpose: CLIL as a way to bring meaning and motivation into EFL contexts. Asian EFL Journal 15(4). 138-159.

Rings, Lana. 1986. Authentic language and authentic conversation texts. Foreign Language Annals 19(3). 203-208.

Soh, Hooi Ling. 2009. Speaker presupposition and mandarin Chinese sentence-final le1: A unified analysis of the "change of state" and the "contrary to expectation" reading. Natural Language \& Linguistic Theory 27(3). 623-657.

Su, Danjie. 2017. Significance as a lens: Understanding the Mandarin ba construction through Discourse Adjacent Alternation, Journal of Pragmatics 117. 204-230.

Su, Danjie \& Hongyin Tao. 2014. Using authentic materials in teaching spoken language and material development: Interview with Dr. Hongyin Tao, the author of Working with Spoken Chinese. Guoji Hanyu [World Chinese Language Journal] 3. 105-112.

Tao, Hongyin. 2005a. The gap between natural speech and spoken Chinese teaching material: Toward a discourse approach to pedagogy. Journal of the Chinese Language Teachers Association 40(2). 1-24. 
Tao, Hongyin. 2005b. Book review: Tell it like it is! (Text with DVD); natural Chinese for advanced learners, by Jianqi Wang. Journal of the Chinese Language Teachers Association 40(2). 117-125.

Tao, Hongyin. 2011. Working with spoken Chinese. Center for Advanced Language Proficiency Education and Research (CALPER) Publications, Pennsylvania State University. State College, PA.

van den Berg, Marinus \& Guo Wu. 2006. The Chinese particle le: Discourse construction and pragmatic marking in Chinese. New York: Routledge.

Wang, Qingyun (王青云) \& Jiafa Peng (彭家法). 2013. 英语为母语留华学生“了1”和“了2”的习得 顺序研究 [On the different acquisition order of “le 1" and “le2” for overseas students with English as mother language]. 合肥学院学报(社会科学版) [Journal of Hefei University(Social Sciences)] 30(6). 89-93.

Wang, Yiwen (王艺文). 2015. 韩国留学生习得“了(le)”的偏误调查分析 [An analysis on errors of “le” by Students from Korea]. 海外华文教育 [Overseas Chinese Education] 76(3). 344-350.

Webb, Stuart. 2010. A corpus driven study of the potential for vocabulary learning through watching movies. International Journal of Corpus Linguistics 15. 497-519.

Wen, Xiaohong. 1995. Second language acquisition of the Chinese particle le. International Journal of Applied Linguistics 5(1). 45-62.

Yu, Youlan (余又兰). 1999. 汉语“了”的习得及中介语调查与分析. 第六届国际汉语教学讨论会论 文选, 244-256. 北京: 北京大学出版社.

Zhou, Xiaobing (周小兵) \& Dan Ouyang (欧阳丹). 2014. 日本学习者句末助词“了2”的习得情况考 察 [An investigation on the acquisition of Chinese particle le2 of Japanese students]. 华文 教学与研究 [TCSOL Studies] 56(4). 8-15.

Zyzik, Eve \& Charlene Polio. 2017. Authentic materials myths: Applying second language research to classroom teaching. Ann Arbor, MI: University of Michigan Press.

\section{Bionotes}

\section{Danjie Su}

Danjie Su, PhD (UCLA, 2017), is an Assistant Professor of Chinese at the University of Arkansas. She specializes in applied linguistics (SLA), Chinese linguistics, discourse pragmatics, and sociocultural linguistics. Her research focuses on linguistic choice-making in Chinese discourse and its L2 pedagogical application. She has published in journals such as Discourse Studies, Journal of Pragmatics, Chinese Language and Discourse, and Journal of Chinese Linguistics. She is a founding co-editor of Guoji Hanyu, a journal in Chinese as a second language.

\section{Hongyin Tao}

Hongyin Tao is Professor of Chinese language and linguistics and applied linguistics and coordinator of the Chinese language program at UCLA. His areas of expertise include Mandarin discourse and grammar, corpus linguistics, sociocultural linguistics, and applied linguistics. Some of his recent publications include Integrating Linguistics Research with Chinese Language Teaching and Learning (John Benjamin, 2016), Chinese under Globalization (World Scientific, 2011) and Working with Spoken Chinese (Penn State University, 2011). 